\title{
ANALYSIS OF SUSTAINABLE COMPUTING FOR MAINSTREAM AGRICULTURAL AND RURAL APPLICATIONS IN DEVELOPING COUNTRIES
}

\author{
Fardeen Dodo ${ }^{1}$, Charles Reith ${ }^{2}$ \\ ${ }^{1}$ School of Business and Entrepreneurship, American University of Nigeria \\ ${ }^{2}$ School of Arts and Sciences, American University of Nigeria \\ E-mail address: nkasiobisilasoguzor@yahoo.com
}

Keywords: analysis of sustainable computing; mainstream agricultural; developing countries

\begin{abstract}
Effective utilization of Information and Communication Technologies (ICTs) has been identified as a sure route for agriculturists and rural inhabitants of developing countries to take advantage of modern technology and survive at the least if not actively participate in global trend of events. However, pervasive complexities in developing countries such as unreliable grid electricity, limited availability of resources, and climate change pose serious challenges to the use of ICTs; these create an urgent need to find sustainable alternatives, especially in rural areas that sharply depend on agriculture for livelihoods. This research involved a comprehensive assessment of the potential of sustainable computing as a solution to the aforementioned challenges for agricultural and rural applications in developing countries. Primary data was obtained from 77 respondents in nine developing countries using questionnaires. Respondents came from varying,largely rural occupations such as animal rearing, agricultural marketing, crop farming and agricultural research and extension. Solar-powered computers were identified as one of the most strategic and relevant solutions to the current limits to access of rural people - especially from agricultural backgrounds who have much to gain from improved access to information and computing technology (ICT). To strike a balance between affordability of mainstream respondents and their need for greater ICT access, we identified integrated netbook-scalesolar powered laptop as the most relevant, which can satisfy the identified ICT needs, plus - besides powering the computer - will power mobile phones and other portable ICT devices. We determined that solar powered computers cangreatly increase access to ICTs benefits to rural, off grid societies and yield carbon savings of up to $22 \mathrm{~kg}$ of $\mathrm{CO}_{2}$, per year. The results of our research are intended to be helpful in promoting off-grid access to ICT in rural societies so as to improve agriculture and extend the additional benefit of "bridging the digital divide in a way that advances sustainable development.
\end{abstract}

\section{INTRODUCTION}

For as long as crop cultivation and animal rearing have existed, so too has the need for information and communications of some sort to make the best value of the produce, through for example better farming practices, alternative markets, and pests and diseases control. The importance of information and communications even increased, as farming became the mainstay of civilization. The industrial revolution greatly changed the profile of agriculture and more rapidly increased technological breakthroughs that improved productivity throughout the world. This was mainly enabled by the rapid evolution of technologies not only for on-farm practices, but also offfarm activities such as transportation, information and market systems. This complex technological shift has however not extended far beyond the developed countries, with the exception of small portions of Latin America, North and South Africa and Asia, where it has only been adopted by large national or foreign farms that have the necessary capital (FAO, 2000).

The vast majority of the farmers in developing countries have therefore continued to rely on traditional means of farming, which are inadequate to compete with speedily evolving methods of modern technology and innovation. Notwithstanding this technological deficit, the role of 
agriculture in developing countries will only continue to grow in importance, as nearly all of the forecasted population growth of a third of the currently world's roughly 7 billion by 2050 will happen in the developing countries (FAO, 2009). This shall inevitably mean more productivity on the part of the farmers, more yields and more processing activities to continue to provide food and fibre for the growing population.

The evolution of Information and Communication Technologies (ICTs) is therefore well timed, and presented immense opportunities for rural farmers to begin to narrow the information and knowledge gap existing between them and their counterparts in developed societies. Over time, many case studies have accumulated of successful applications of ICTs for improved farm practices, pursuing better markets, managing threats of pest and diseases and other farm related issues and in enabling farmers properly plan, organize, direct and control farming activities in a way they optimize farm income. On the face of globalized agricultural markets, ICTs have culminated into necessary tools if agriculturists and rural people, are to survive at the least, if not actively participate in the fast changing global trends of farm produce markets and lifestyle.

Combined forces of climate change, inadequate resources, poor infrastructure, fundamentally electricity are however standing in the way of attaining increased ICTs access in rural societies of developing countries. Connecting this proportion of the world to the grid is not only very expensive for developing countries, but as well confronts serious climate change implications, which even at present, are proving to be more impactful on this group of countries through changing weather patterns, and creating droughts in some regions and floods in others (Heeks and Ospina, 2012).

Factoring in all these challenges, the need to seek for sustainable alternatives therefore is becoming apparent, in ways that improved ICTs utilization by agricultural practitioners and rural people is realized, and potentially other sustainable development efforts are promoted as well. The questions; what would represent a sustainable ICT system for mainstream agricultural and rural applications, and what is its potential environmental benefit? become instructive. The objective of this paper is therefore to analyse: What would constitute a sustainable computing system for mainstream agricultural and rural applications, and what the needs, preferences and affordability of potential users are.

\section{SUSTAINABLE COMPUTING FOR MAINSTEAM AGRICULTURAL AND RURAL APPLICATIONS}

\subsection{CONCEPTUAL FRAMEWORK}

Sustainable Computing is a relatively novel and fast expanding field of study. There are several other names that are given to it, such as Green Computing/IT, Eco-friendly Computing etc., which are also used to mean the same thing. Howell, 2007 defined sustainable computing, as a one that considers the total cost of ownership, total environmental impact and total benefit of technology systems. On the other hand, Murugesan 2008 builds details upon this, by defining it as the study and practice of designing, manufacturing, using, and disposing of computers, servers, and associated subsystems such as monitors, printers, storage devices, and networking and communications systems efficiently and effectively with minimal or no impact on the environment. He further sectioned the main areas of life cycle of computing devices that are needed to be environmentally benign from design to disposal (Fig. 2.1). 


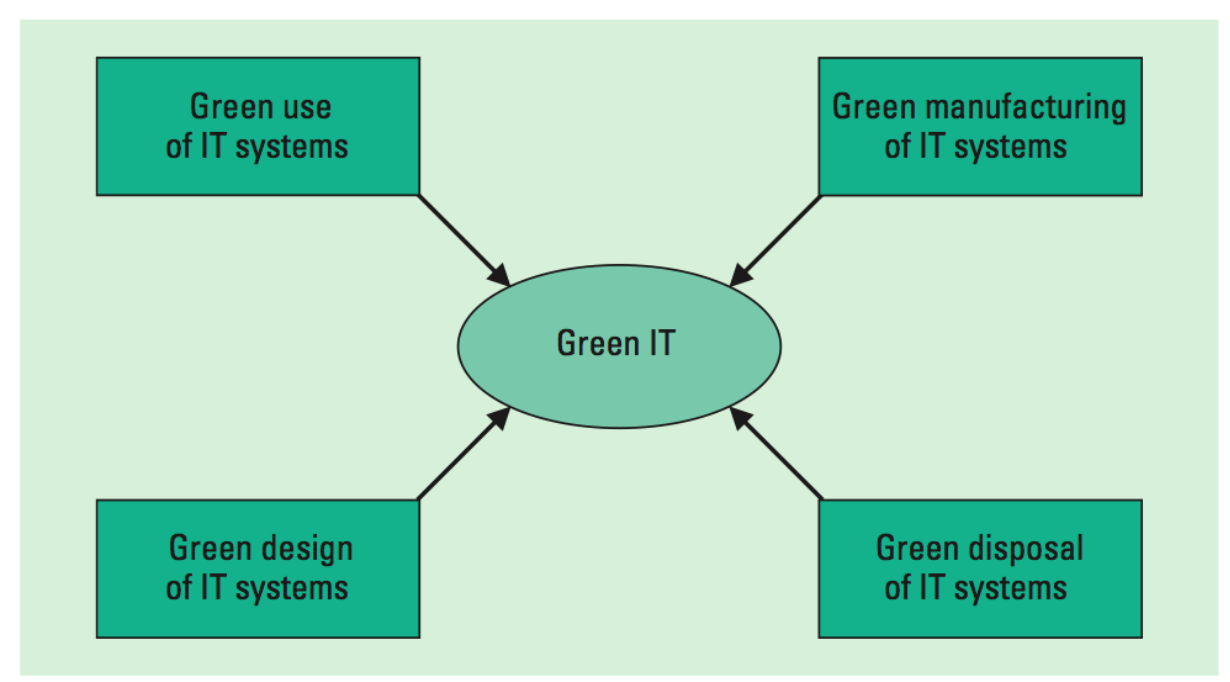

Fig. 2.1 Components of Green Computing/IT System

(Source: http://www.cse.chalmers.se/ davidwh/eac/papers/GreenPaper.pdf)

Sustainability practices are not only limited to the specifically highlighted points in the figure above, but as well other related points such as sustainable powering of the computers, data centers, network equipment etc. under the Green Use of IT systems, and use of environmentally benign materials and processes in Green Manufacturing of the systems.

Furthermore, in the forecast of the future of ICT by the Royal Academy of Engineering (RAE, 2012), indicated that computer manufacturing in the near future will have to consider making devices from eco-friendly materials that are more energy efficient, emit less heat, and at a cheaper development cost. In addition to these qualities, RAE, 2012 also identified the need for encouraging proper user attitude and use of more sustainable infrastructure. This adds attitude to the picture, which is indeed relevant and can greatly contribute to sustainability efforts.

Additionally, researches are continuously providing compelling reasons as regards to why computing and ICTs generally need to begin taking environmentally benign directions to ensure their future availability and maintain environmental quality. Murugesan (2008) noted that the growing accumulation of greenhouse gases is changing global climate and weather patterns thereby creating droughts in some countries and floods in others, pushing global temperature upwards and posing great problems to the world's climate.

Electricity, upon which ICTs thrive, has particularly been identified as a single huge contributor to these global emissions; and in addition to contributing to climate change also causes other negative effects such as acid rain, smog and respiratory infections (Murugesan, 2008). Importantly, what is making computers even more central to sustainability practices is not simply the immense carbon emissions due to them; of up to a tonne per computer per annum (Murugesan, 2008), but also their major role in reducing greenhouse emissions of other industries and inevitable applications in several other socioeconomic activities (Fernando and Okudo, 2009).

Moreover, Gartner, 2007 estimated that the aggregate global emissions caused by the ICT industry to be about $2 \%$, which is equivalent to that caused by the aviation industry and considered unsustainable, and that in the next five years, increasing financial, environmental, legislative and risk-related pressures will force IT organizations to have to get 'greener' and be more environmentally benign.

From the foregoing, the need therefore to identify priority points of action in promoting sustainable computing in rural and agricultural settings becomes instructive. In this regard, (OECD, 2009) identified the usage phase of the entire life cycle of ICT devices as by far the most important with regards to reducing emissions and improving environmental friendliness (Fig 2.2). The figure clearly illustrates the importance of the usage phase of computing to sustainability, relative to other phases and underscores the importance of using sustainable energy systems in powering ICT devices, especially in rural areas, where electronic wastes (eWaste) may not pose serious disposal hazards. 
Global warming potential (GWP) over 100 years

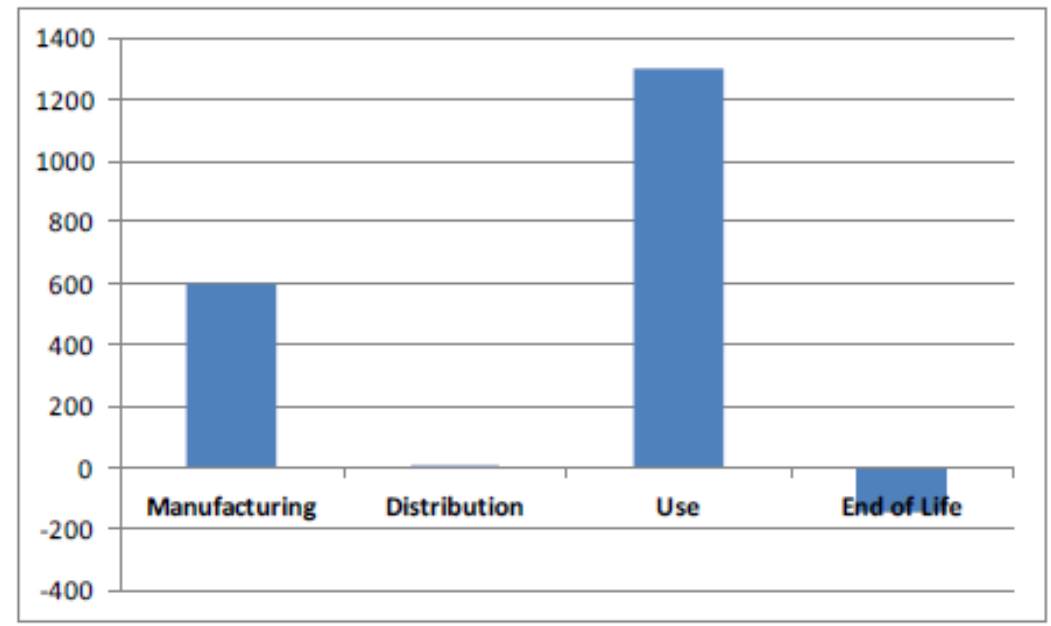

Fig. 2.2Life-cycle global warming potential of a PC with peripherals Source: OECD, 2010

Gartner's prediction was witnessed in streams of efforts in the developing world to promote lower carbon computing in many countries, including the UK (Parliamentary Office of Science and Technology, 2008) and Japan's 2050 targets of achieving reduced ICT industry's emissions by 60 80\% (Fujinuma, 2009). Another effort that fit in this forecast is Australia Green IT Agenda's series of initiatives across Industry, Health, Education, Building Management Systems, Transportation, Energy Production, Distribution and Industrial Processes (Ruth, 2011).

Additionally, Heeks and Ospina, 2012 identified an acute need for new integrated ICT policy approaches and regulatory environments in developing countries that will foster effective mitigation, adaptation and monitoring strategies of climate change, especially considering the magnitude of their impacts in those countries. They also modeled the areas of action in a way that more integrated policies are developed that concurrently address ICTs, climate change and development (ICCD) needs (Fig. 2.3).

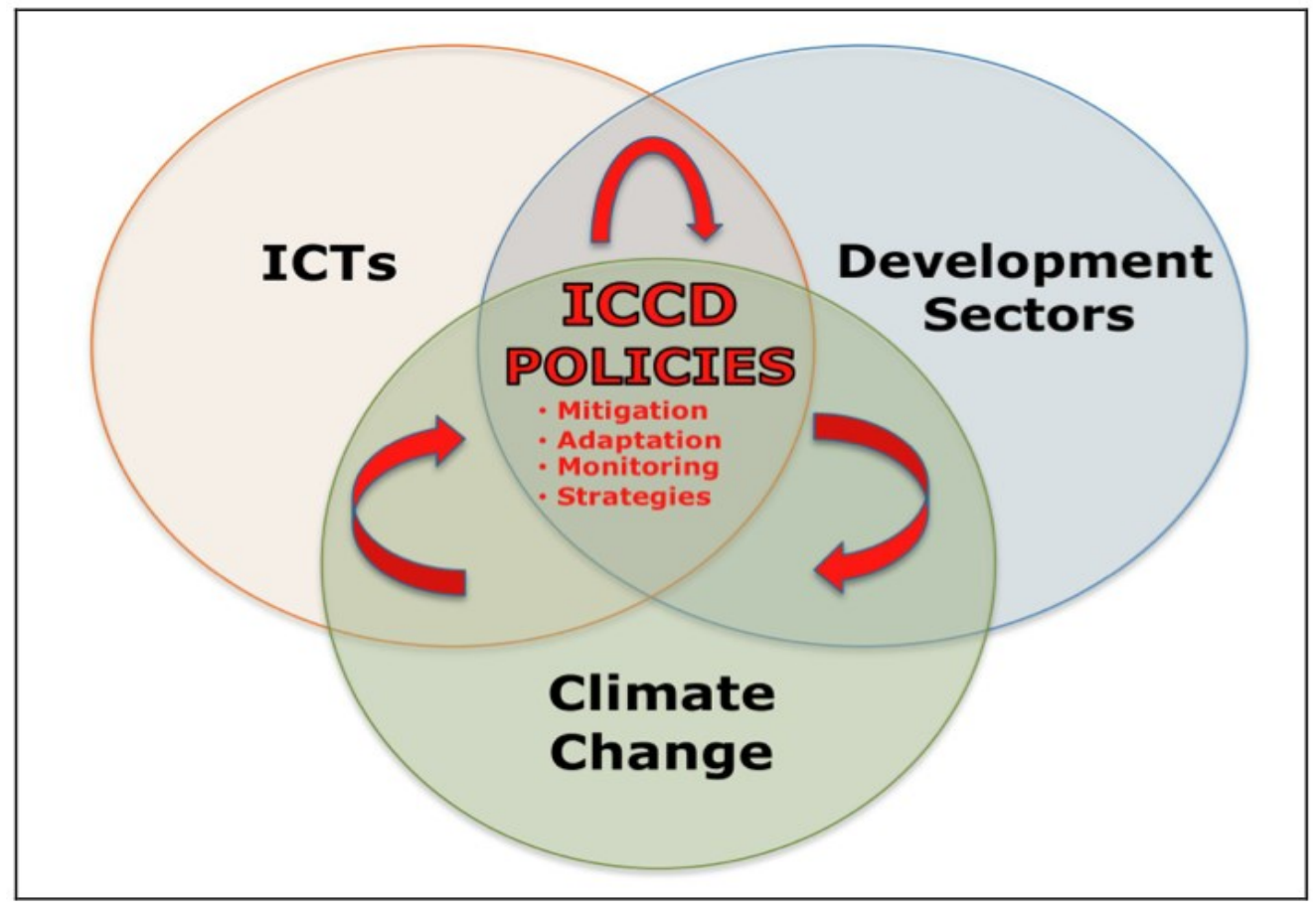

Fig. 2.3 Overlapping fields of Action in Developing Countries (Source: http://www.niccd.org/ICCD_Policy_Guidance_Paper.pdf) 
The figure also points out the specific areas needed to be covered by ICCD policies, including mitigation of potential environmental degrading practices, making the environment more resilient, setting effective strategies together monitoring mechanisms.

\subsection{SOLAR PHOTOVOLTAIC APPLICATION}

There are many grid, mini-grid and off-grid renewable energy alternatives that can be employed to extend electricity and the benefits of computing and ICTs to the rural people ranging wind energy, solar photovoltaic and thermal energy, biomass energy, geothermal energy and hydroelectric energy. Of all these however, current trends in technological advances and market situations are revealing competitive edge that solar photovoltaic electricity has over the rest, especially as regards to powering portable electronic devices.

Firstly, the theoretical resource potential of global solar energy far exceeds demand (EPIA, 2007). Despite the technological advances and market growth identified by Timilisina, et al (2011), utilization of this huge energy source is still considered negligible (IEA, 2009). Additionally, according to General Electric, which is one of America's leading multinational conglomerates involved in developing a wide range of Energy, Technology Infrastructure, Capital Finance and Consumer and Industrial products, solar PV electricity will be cheaper than coal in less than 5 years (Wingfield, 2011). This was envisaged to occur due among others, to technological breakthroughs as introduction of thin film solar PV cells and dropping cost of manufacturing equipment.

Regarding the availability of solar resources around the world, the Centre for Global Development (2008) presents a very good spatial distribution map of average daily solar irradiance around the world (Fig. 2.4), which indicates very good solar radiation levels in the developing regions of the world, such as Africa, Asia and Latin America.

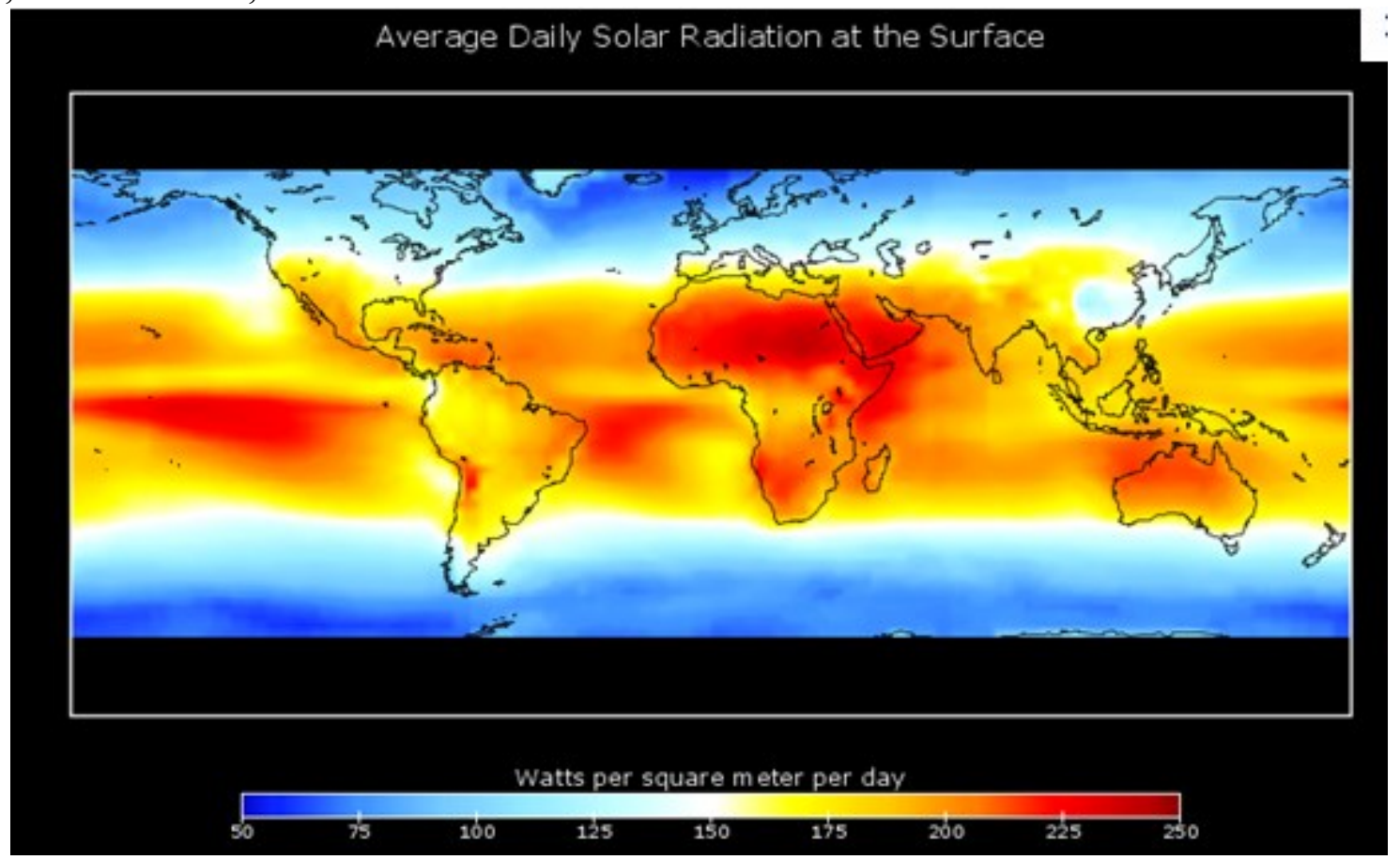

Fig. 2.4 Global Map of Average Solar Radiation

(Source: http://blogs.cgdev.org/globaldevelopment/2008/02/a-solar-future-for-the-world-b.php)

Moreover, Timilisina et, al (2011) identified many fiscal and regulatory instruments including tax incentives, direct incentives, loan programs, construction mandates and renewable portfolio standards that have been employed by various governments to increase output of solar energy. The technological advancements also made available various designs and solutions that are convenient for off-grid, to even mobile application (Timilisina ET, al (2011), Serano (2003), which no other renewable energy technology has equalled yet.Based on the above reasons, it is therefore concluded that using solar PV - powered computing represents the most suited sustainable computing option, hence were considered in this paper. 


\section{RESEARCH METHOD}

The research involved a descriptive investigation of the research objective, using both secondary and primary information. Secondary information used was obtained from published and unpublished literature. Primary data, which is obtained directly from the research subjects (Driscol, 2010) was collected through a sample of agricultural and rural development interest groups. This was not only to augment secondary data, but also avoid the trickle-down approach to development, which was discovered by Chaitrong (2009) and Niboh (2009) to lead to irrelevant and sometimes completely non-useful results to development subjects. While the consideration of solar powered computing devices was guided by literature, primary research was conducted to test whether the consideration is what applies to the research subjects.

\subsection{STUDY AREA}

Though the terms 'Developing countries' have many definitions, they do however generally point to a same collection of countries. In general, developing countries are those with low standard of living and underdeveloped industrial sector. The United Nations (2011) points out that though the terms 'developed' and 'developing' with regards to country grouping have no established conventional rooting, in common practice however, Japan in Asia, Canada and the United States in northern America, Australia and New Zealand in Oceania, and Europe are considered "developed" regions or areas. The International Monetary Fund (2009) on the other hand uses three parameters in discerning between developed and developing countries; i.e. per capita income level, export diversification and degree of integration into the global financial system. The countries therefore that are low concerning these parameters are considered as developing countries otherwise referred to as developed.

Similarly, the World Bank (ND), categorized countries in according to their per capita level of income; into low income, (those with $\$ 1,005$ or less), lower middle income, $(\$ 1,006-\$ 3,975)$, upper middle income, $(\$ 3,976$ - $\$ 12,275)$; and high income, (i.e. those with $\$ 12,276$ or more). Apart from political and economic considerations that are often used to classify them, they do with regards to agricultural and rural development; tend to have common generic and often locational challenges that researchers often find it advantageous to collectively study. The study area comprises therefore of the entirety of developing countries across Africa, Asia, North America, Oceania and the Antarctic based on a sample from a few of them. For the purpose of the study, the UN 2011 definition was adopted, for this paper.

\subsection{SAMPLING}

A standardized online survey instrument was developed with google forms and used to harness the basic information needed for the research. The questionnaire sample was purposively drawn from the main developing regions of the world. Due to the several constraints of poor internet and electricity access by the rural people across developing countries, farmer organizations and rural development interest groups were targeted. Many agricultural and rural development groups in Africa, Asia and South America were contacted through their official e-mail addresses and other regional and national mailing lists. The survey was also shared with many relevant international organizations and interest groups, including: The Barza project (http://www.barzaradio.com/); African Farmers' Network (http://twitter.com/african_farms); Africa Rural Connect (http://www.arc.peacecorpsconnect.org/); SciDev.Net; African Research and Education Network (http://www.afnog.org/mailman/listinfo/afren); and other online communities of African farmers and rural interest groups. 


\section{RESULTS}

\subsection{NATIONALITY OF RESPONDENTS}

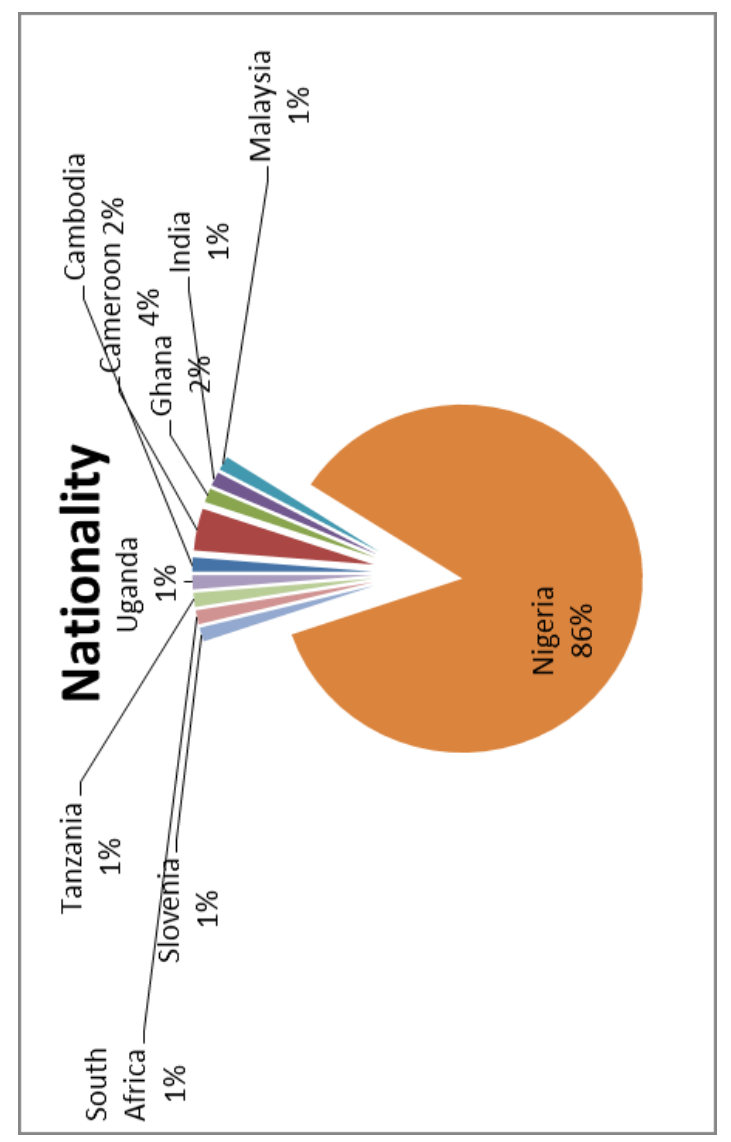

Analysis: From the results, nationality spread was largely skewed to Nigeria, though avenues used for data collection had people from many other developing countries, particularly Africa. It is however important to note that Nigeria, has higher internet access, relative to other African countries, as noted by the Internet World Statistics; (http://www.internetworldstats.com/top20.htm). Globally, Nigeria stands out as the $11^{\text {th }}$ of the top 20 countries in terms of Internet Access, with $26 \%$ of their population having access to the internet. This further means that the questionnaire results may not specifically apply to the other African or developing countries generally, due to the nationality imbalance in the data.

Fig 4.1. Nationality of Respondents

\subsection{OCCUPATION OF RESPONDENTS}

Table 4.1 Occupation

\begin{tabular}{|l|l|l|}
\hline Occupation & Frequency & Percentage (\%) \\
\hline A = Crop Farming & 15 & 15 \\
\hline B = Farm Products' Processing & 5 & 5 \\
\hline C = Agricultural Marketing & 3 & 3 \\
\hline D = Land and Rural Development Administration & 1 & 1 \\
\hline E = Agricultural Research and Extension & 20 & 20 \\
\hline F = Related NGOs, Cooperatives and Institutions & 15 & 15 \\
\hline G = Animal Rearing & 21 & 21 \\
\hline H = Trading & 4 & 4 \\
\hline I = Others & 16 & 16 \\
\hline Total & $\mathbf{1 0 0}$ & $\mathbf{1 0 0}$ \\
\hline
\end{tabular}

Analysis: The results indicated that over $30 \%$ of respondents have more than one occupation. Animal rearing is one single most practiced occupation, accounting for $21 \%$ of respondents. Also, rural development administrators, traders, marketers and farm products' processors are least represented and accounted for only $12 \%$ of the respondents. In addition the main agricultural practitioners, other rural-based professionals from other industries, such as engineering, health and civil service have also filled the questionnaire, which in some way reveals interest in the product even by professionals of other non-agriculture and related industries. 


\subsection{COMPUTER PREFERENCE}

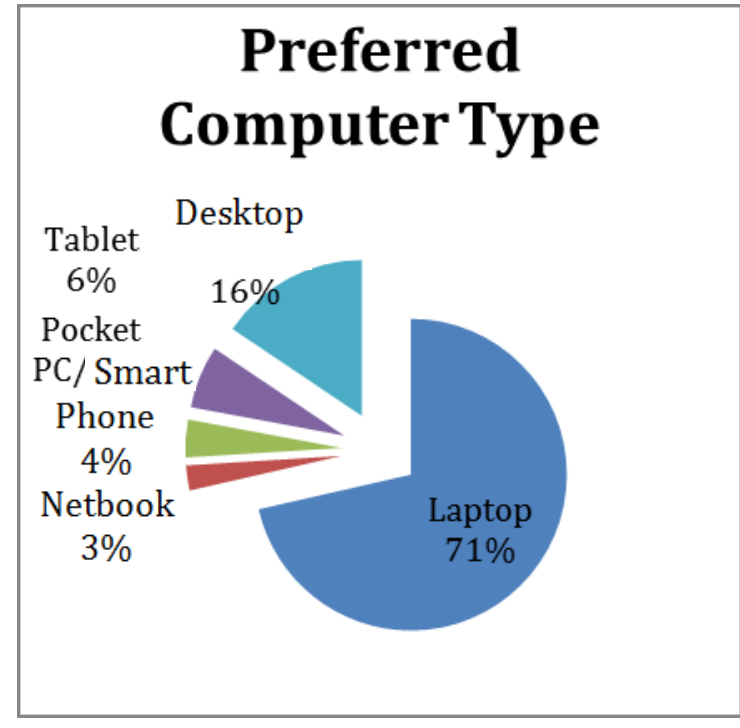

Fig. 4.2 Preferred Computer Type

Analysis: The results indicate that overwhelming majority of respondents prefer laptops to any other types of computer. This finding is however not in conformity with the usual practice by civil societies and ICT stakeholders of deploying netbook computers for rural applications, such as the One Laptop per Child (OLPC) computers, and the Intel classmate PC; which are particularly designated as the ultimate devices for rural applications. Computer Aid International, 2008 also, following a comprehensive low power pc research project, prioritized the Asus EEE netbook PC over other computers in terms of suitability in rural areas of developing countries. However, it is important to note that netbook computers have lower familiarity, in comparison to laptops, as reported by Netputing, 2009, and get mistaken for laptops. Also, considering the poor rural ICTs literacy levels identified as major constraints, high capacity computers may not be really needed, even when they are actually preferred.

\subsection{OTHER DEVICES}

Table 4.2 Other Devices

\begin{tabular}{|l|l|l|}
\hline Device & \multicolumn{1}{l|}{ Frequency } & \multicolumn{1}{l|}{ Percentage (\%) } \\
\hline A = Mobile Phone & 62 & 47 \\
\hline B = Radio & 30 & 23 \\
\hline C = MP3 Player & 9 & 7 \\
\hline D = iPod/iPod Touch & 23 & 17 \\
\hline $\mathbf{E}=$ Other & 8 & 6 \\
\hline Total & $\mathbf{1 3 2}$ & $\mathbf{1 0 0}$ \\
\hline
\end{tabular}

Analysis: Results indicated that almost half of the respondents prefer to power mobile phones in addition to the computers. Up to $70 \%$ of them also prefer to power both radio and mobile phone, in addition to the computer system. This is consistent with a BBC report, 2012 (http://www.bbc.co.uk/news/world-africa-15659983), which indicated high and growing mobile phone penetration in Africa of nearly 650 Million subscribers as at 2011, 93 Million of whom are in Nigeria alone. Additionally, the responses revealed additional devices that respondents also prefer to power with the solar solution, including; Data Acquisition/Logging System, GPS, Lighting, Household/Kitchen Appliances, Television and Printers. Although some of these, like kitchen appliances are not ICT devices, the responses point to the urgent need for reliable electricity to power, even other non-ICT devices, possibly in the light of poor electricity supply, that was identified by Gulati, 2008. 


\subsection{PREFERRED COMPUTER ATTRIBUTES}

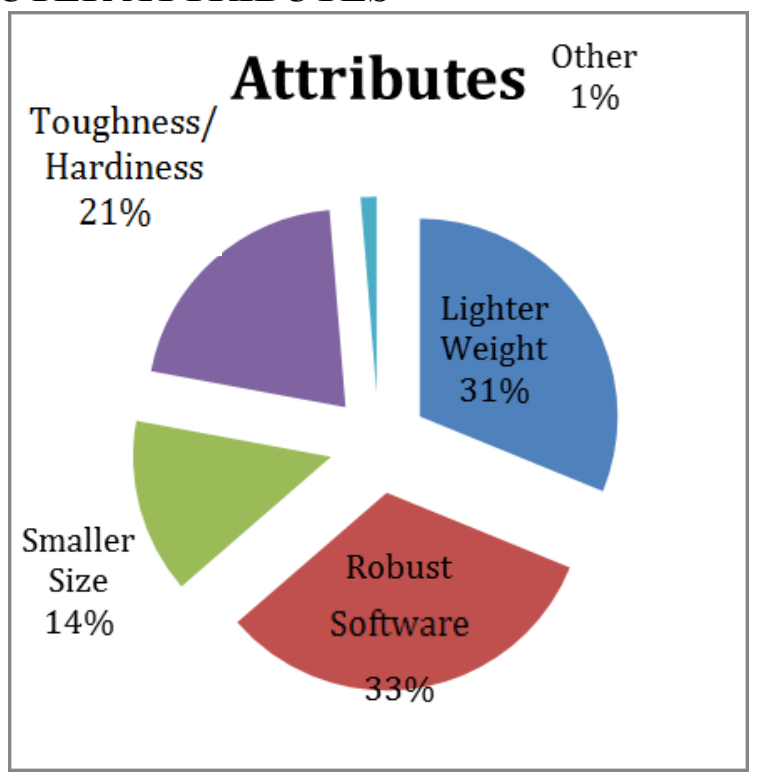

Fig. 4.3 Preferred Computer Attributes

Analysis: Results indicated that robust software, lighter weight and toughness and hardiness are the main preferred computer attributes by respondents. Unfortunately, no secondary information was found on this particular issue, and as such no comparison was made with these results.

\subsection{AFFORDABILITY}

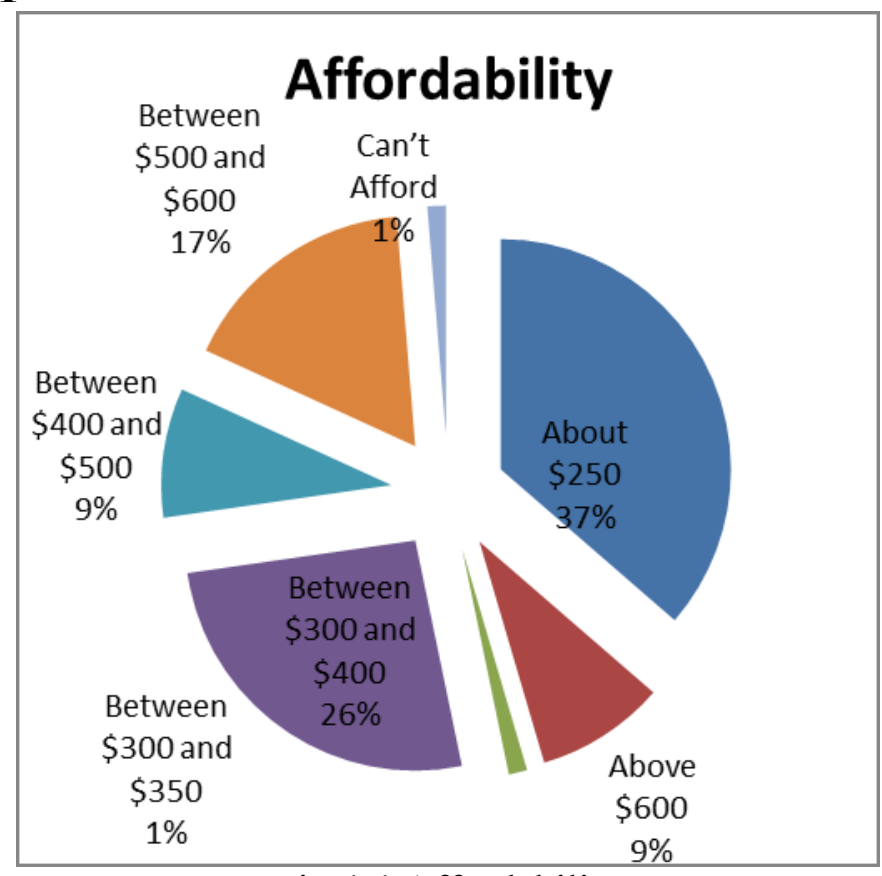

Fig 4.4 Affordability

Analysis: The data revealed that over $60 \%$ of the respondents can afford at a price below $\$ 400$. These results relate well to the findings of World Bank, 2012, of the poor resource availability of most rural farmers and agricultural practitioners in developing countries, while also indicating the importance of identifying cheaper systems to promote affordability.

\section{COMPUTER SAMPLING}

In accordance with the majority of responses, the main product preferences identified were light weight, ruggedness, durability, reliability, affordability and ease of maintenance. A number of 
online reviews on computer hardware were consulted and a sample of computers that satisfy most of the user preferences were collected. Over the course of the sampling process, it was realized that laptops are generally very expensive, especially those with larger screen size and advanced specifications.

Those with smaller screen sizes, longer battery life, higher energy efficiency, lighter, more portable and are relatively cheaper were sampled. All of the computers are Energy Star qualified, and compliant with the international standard for energy conservation of the American Environment Agency, which means that they use $20-30 \%$ less energy than the standard requirement (www.energystar.gov).

A) Samsung Chromebook Series 5-550: This is a strong ultraportable laptop with a 12.1 inch 1280 x 800 Wide Extended Graphics Array (WXGA) screen. It has an Intel Celeron 867, 1.3 GHz dual core processor and a 4GB Random Access Memory (RAM). It runs on Solid State Drive, which is energy friendly with no moving parts and has a 4-cell lithium polymer battery that lasts for up to 6 hours of operation. The computer weighs $1.4 \mathrm{~kg}$ and has dimensions of $285.75 * 210.82 * 17.8 \mathrm{~mm}\left(\mathrm{~W}^{*} \mathrm{D} * \mathrm{H}\right)$. It costs $\$ 549$.

http://www.cnet.com/laptops/samsung-chromebook-series-5/4505-3121_7-35308790.html

B) Toshiba Satellite T135D-S1324: This is a strong laptop with a 13.3' 1366 x 768 HD screen. It has a 4GB RAM and an AMD Turion Neo X2 mobile L625 / $1.6 \mathrm{GHz}$ dual core processor. It has a 6 cell lithium ion battery, which supports up to 6.6 hours of operation. It weighs $1.81 \mathrm{~kg}$, with dimensions of $322.58 * 223.52 * 33.01 \mathrm{~mm}(\mathrm{WDH})$. It costs $\$ 549$.

http://www.cnet.com/laptops/toshiba-satellite-t135d-s1324/4505-3121_7-33948076.html

C) Lenovo Thinkpad Edge E325: This computer has a 13.3" HD (1366x768) LED Anti-glare screen. It is durable, strong and optimized for mobility. It has a 4GB of RAM, with an AMD E350 dual core processor and a 6 cell lithium ion battery which supports up to 8 hours of operation. It weighs $1.74 \mathrm{~kg}$ and has dimensions $\left(\mathrm{W}^{*} \mathrm{D} * \mathrm{H}\right)$ of $322 \times 224 \times 26.7 \sim 30.9 \mathrm{~mm}$. Its price is up to $\$ 579$.

(http://www.cnet.com/laptops/lenovo-thinkpad-edge-13/4505-3121_7-33939705.html, http://www.cclonline.com/content/pdfs/cqmkj7s9fXDsVu5OEYg4dg-3d-3d.pdf)

D) Acer Aspire Timeline U M3 581T: This is durable low power laptop computer, with a 15.6 inch 1366 x 768 glossy screen. It has an Intel core i3 processor and a 4GB RAM. It has a 6 cell lithium ion battery that supports up to 7 hours of operation. It weighs $2.07 \mathrm{~kg}$, with $2.1 \mathrm{~mm}$ width. Costs $\$ 721.120$

http://www.laptopsdirect.co.uk/Acer_Aspire_Timeline_U_M3_Core_i3_Ultrabook_NX.RY 8EK.001/version.asp\#maindesc

E) Asus U32U Brazos Notebook: This is a low power portable laptop with a 13.3 inch (1366x768) High Definition screen. It has an AMD Fusion APU E-450/C-60/C-50 Processor and a 4GB RAM. Its 8 cell lithium ion battery enables computing for up to 10 hours. It costs up to $\$ 479$. Its dimensions are $328 \times 238 \times 22.5 \mathrm{~mm}(\mathrm{WxDxH})$ and weight is $1.75 \mathrm{~kg}$.

(http://www.asus.com/Notebooks/Superior_Mobility/U32U/\#specifications, http://www.thegoodguys.com.au/buyonline/Asus_U32U_AMD_Brazos_Dual_Core 13.3\%2 2_Notebook_U32U-RX019V) 
Table 5.1: Computer Comparison

\begin{tabular}{|c|c|c|c|c|c|c|}
\hline Option & Processor & RAM & Battery & Weight & $\begin{array}{l}\text { Price } \\
\text { (\$) }\end{array}$ & $\begin{array}{l}\text { Disk } \\
\text { Space }\end{array}$ \\
\hline $\mathbf{A}$ & Intel Celeron $867,1.3 \mathrm{GHz}$ dual core & 4GB & 6 hours & $1.4 \mathrm{~kg}$ & 549 & $16 \mathrm{~GB}$ \\
\hline $\mathbf{B}$ & $\begin{array}{l}\text { AMD Turion Neo X2 mobile L625 / } 1.6 \\
\text { GHz dual core }\end{array}$ & 4GB & $\begin{array}{l}6.6 \\
\text { hours }\end{array}$ & $1.81 \mathrm{~kg}$ & 549 & $320 \mathrm{~GB}$ \\
\hline $\mathbf{C}$ & AMD E350 dual core & $4 \mathrm{~GB}$ & 8 hours & $1.74 \mathrm{~kg}$ & 579 & 320GB \\
\hline $\mathbf{D}$ & Intel core i3 & 4GB & 7 hours & $2.07 \mathrm{~kg}$ & 721 & 256GB \\
\hline $\mathbf{E}$ & AMD Fusion APU E-450/C-60/C-50 & 4GB & 10 hours & $1.75 \mathrm{~kg}$ & 479 & 320GB \\
\hline
\end{tabular}

Source: Field Research

Given the fact that all the sampled devices have good performance specifications and environmental friendliness, selection was made on cost of the devices. Option E therefore was chosen for the subsequent stages of the work.

\subsection{AVERAGE LOAD SIZING}

According to the manufacturers of the Asus U32U, its battery has 83 Watt-hours capacity. This means that, without any losses, 1Watt solar panel would charge the battery to fill over a period of 83 hours of full sunshine and a 30Watt panel would charge it over a period of $83 / 30=2.7$ hours of full sunshine. Also, according to CNET's review of the 20 longest lasting mobile phone batteries (http://reviews.cnet.com/2719-11288_7-290-2.html), the power consumption of the first is 3300mAh; which equals 3.3 Watt-hours.

So in all, the laptop computer and mobile phone alone will require approximately 86.3 watt-hours of solar energy to be fully charged. This is not inclusive of the energy use to maintain battery level at the times when the device would be operational and charging. There are also other devices, such as radio that the primary survey revealed the need to provide power for. Specific consumption of these was not estimated, because not many radios have built-in rechargeable batteries that can be directly considered in the load sizing. There are also other ICT devices, revealed by the primary study, such as data acquisition and logging systems and GPS that need to be catered for, in the system sizing.

One of the ways to address these issues, as related by Honeyman and Robinson (2007), is to double the concrete estimate, especially considering the fact that not all days may have full sunshine levels and there is roughly an energy loss of about 33\% while charging batteries. Applying these considerations therefore, the estimated daily load size of the system became 173.2 watt-hours per day. Honeyman and Robinson (2007) estimated the daily peak sunshine hours to be between 10:00am and $3 \mathrm{pm}$. To determine the solar panel capacity needed, the number of watt-hours; 173.2 was divided by the number of sunshine hours; 6 . This yielded 28.86 Watt panel capacity. A 30Watt solar panel was therefore considered to be optimum, hence used for the system.

\subsection{ENVIRONMENTAL BENEFITS}

A solar powered computing unit would have immense environmental benefits, both due to it and in the potential spill over effects it may trigger. Encouraging solar powered computing can not only encourage sustainable use of ICTs, but also potentially, trigger other renewable electricity deployments in other applications, such as homes and businesses. The respondents' comments very well identified these potential non-ICT uses, to which they would like to put the product's power system; including lighting, printers, television among others.

According to Biomass Energy Centre (BEC), 2012, carbon constitutes $85 \%$ of fossil oil content, and every generation of 1 megawatt-hour of energy yields $350 \mathrm{~kg}$ of carbon emissions, which is equivalent to $0.35 \mathrm{~kg}$ per kilowatt-hour. From the load-sizing estimate therefore:

Annual kWh of energy needed will be $0.1732 * 360=62.352 \mathrm{kWh}$ 
The annual carbon savings of the product usage will be $62.352 * 0.35=21.82 \mathrm{~kg}$. Specifically therefore, each solar powering unit can save of about $22 \mathrm{~kg}$ of harmful carbon emissions, annually.Furthermore, due to the rising relevance of ICTs in other socioeconomic activities, the product can also help in reducing the environmental implications of other industries, as identified by Fernando and Okudo, 2009. Measuring these potential benefits is difficult, and unfeasible in most circumstances; hence comprehensive assessment on them was not made.

\section{CONCLUSIONS AND RECOMMENDATIONS}

At the end of the study, it was concluded that Mobile phones, computers and the radio were discovered as the most important ICT devices for mainstreamagricultural and rural applications, and using solar energy to power them is a very suitable option to achieve computing sustainability. The needs also for the systems to be physically secure, safe and environmentally benign was identified as a needed requirement by many respondents.

Furthermore, while the study was focussing more on the usage part of sustainability, the likely potentials of re-using devices to enhance rural ICTs access were observed, particularly from the angle of taking advantage of the e-waste problems that are worsening in urban Africa. It is therefore recommended that further studies investigate the feasibility of taking opportunity out of this problem to sustainably extend ICTs to rural regions. Subsequent researchers could also dig deeper into more remote regions to investigate the viability of solar powered computing systems. It is also recommended that Nigerian agricultural marketers and entrepreneurs leverage on this new insight to identify new business niches and prioritize their actions.

\section{References}

[1] Adkins, W.D. (2008) Literacy in Africa as a gateway to eradicating poverty Available at: $\mathrm{http} / / \mathrm{www} \cdot h$ hium.com/items/1012649-literacy-in-africa-as-a-gateway-to-eradicating-poverty (Accessed: 19th June, 2012).

[2] Association for Progressive Communications (2012) ICT For Development. Available at: http://www.apc.org/en/taxonomy/term/337 (Accessed: 18th August, 2012).

[3] BBC (2012) Africa's mobile phone industry 'booming'. Available at: http:/www.bbc.co.uk/news/world-africa-15659983 (Accessed: 13th August, 2012).

[4] Biomass Energy Centre (2012) Carbon emissions of different fuels. Available at: http://www.biomassenergycentre.org.uk/portal/page?_pageid $=75,163182 \&$ dad=portal\&_sch ema $=$ PORTAL (Accessed: 10th August, 2012).

[5] Centre for Global Development. (2008) A Solar Future for the World Bank in Southern Africa? Available at: http://blogs.cgdev.org/globaldevelopment/2008/02/a-solar-future-forthe-world-b.php (Accessed: 25th June, 2012).

[6] Chaitrong, W. (2009) Bottom-up approach to development better. Available at: http://www.nationmultimedia.com/2009/08/24/business/business_30110504.php (Accessed: 26th July, 2012).

[7] Christoplos, I. (2010). Mobilizing the Potential of Rural and Agricultural Extension. Rome: Food and Agriculture Organization (FAO). FAO, http://www.fao.org/docrep/012/i1444e/i1444e00.htm, accessed $5^{\text {th }}$ March, 2012

[8] Connect Africa Summit. (2007) Extending Rural ICT Access in Africa. Union, I.T. [Online]. Available at: http://www.itu.int/ITU-D/connect/africa/2007/summit/pdf/s3-backgrounder.pdf (Accessed: 20th July, 2012). 
[9] Department of Posts, Ministry.of Communications, India.(2010) Expression of Interest for Selection of Hardware Vendor for Supply, Installation and Maintenance Services of Peripheral Devices, Operating System and Connectivity for Rural ICT Solution.Post, I. [Online]. Available at:

http://www.indiapost.gov.in/Old/Pdf/RuralICTHardwareEOI_19112010.pdf (Accessed: 30th April, 2012).

[10] Driscoll, D.L. (2010) Introduction to Primary Research: Observations, Surveys, and Interviews. Available at: http://wac.colostate.edu/books/writingspaces2/driscoll--introductionto-primary-research.pdf (Accessed: 15th June, 2012).

[11] Driscoll, D.L., Brizee, Allen (2010) What is Primary Research and How do I get Started? Available at: http://owl.english.purdue.edu/owl/resource/559/01/ (Accessed: 10th June, 2012).

[12] El-Bassam, N., Maegaard, Preben (2004) Integrated Renewable Energy for Rural Communities Elsevier. Available at:

http://www.elsevier.com/wps/find/bookdescription.cws_home/703319/description\#descriptio n (Accessed: 16th August, 2012).

[13] Energy for Development.(2010) Rural Electrification in Developing Countries by the Numbers. Available at: http://www.energyfordevelopment.com/2010/04/rural-electrificationby-numbers.html (Accessed: 12th June, 2012).

[14] European Photovoltaics Industry Association (EPIA).(2007) PV to become a leading world energy market.[Online]. Available at: http://www.rtcc.org/2007/html/dev_solar_epia.html (Accessed: 20th June, 2012).

[15] FAO (2000) The socio-economic impact of agricultural modernization. Available at: http://www.fao.org/docrep/x4400e/x4400e10.htm (Accessed: 17th July, 2012).

[16] FAO (2009) Global agriculture towards 2050.How to Feed the World 2050.[Online]. Available at: http://www.fao.org/fileadmin/templates/wsfs/docs/Issues_papers/HLEF2050_Global_Agricult ure.pdf (Accessed: 14th July, 2012).

[17] Fernando, P., Okudo, A. (2009) Green ICT: A "Cool" Factor in the Wake of Multiple Meltdowns. Pacific, United Nations Economic and Social Commission for Asia and the Pacific. [Online]. Available at:

http://www.unescap.org/idd/working\%20papers/IDD_TP_09_10_of_WP_7_2_907.pdf (Accessed: 16th April, 2012).

[18] Fujinuma, K. (2009) Japan's ICT \& Climate Change Policies and Actions. Available at: http://www.itu.int/dms_pub/itu-t/oth/06/0F/T060F00600F0033PDFE.pdf (Accessed: 14th July, 2012).

[19] Gartner, I. (2007) Gartner Estimates ICT Industry Accounts for 2 Percent of Global CO2 Emissions. Available at: http://www.gartner.com/it/page.jsp?id=503867 (Accessed: 15th June, 2012).

[20] Gourdin, G. (2007) Solar Cell Technology: Current State of the Art. Available at: http://fetweb.ju.edu.jo/staff/EE/khedher/SolarCellsTechnology2.pdf (Accessed: 19th March, 2012).

[21] Greene, J. (2010) The bridge between Farm and Market. Available at: http://ictupdate.cta.int/mobileen/Regulars/Perspectives/The-bridge-between-farm-and-market (Accessed: 20th April, 2012).

[22] Gulati, S. (2008) 'Technology-Enhanced Learning in Developing Nations: A review', International Review of Research in Open and Distance Learning, 9(1), pp. 1-16. 
[23] Haines, R.J. (2006) Overcoming the Technical Challenges Of Providing Distance Education to Developing Countries. Msc thesis.Bowie State University [Online]. Available at: http://citeseerx.ist.psu.edu/viewdoc/download?doi=10.1.1.97.3847\&rep=rep1\&type=pdf.

[24] Heeks, R., Ospina, A. V. (2012) Making Policy on ICTs and Climate Change in Developing Countries. Manchester: Nexus for ICTs, C.C.a.D. [Online]. Available at: http://www.niccd.org/ICCD_Policy_Guidance_Paper.pdf(Accessed: 13th April, 2012).

[25] Hegedus, S., Luque, Antonio (2011) Handbook of Photovoltaic Science and Engineering. Wiley Online Library. Available at:

http://onlinelibrary.wiley.com/book/10.1002/9780470974704;

$\mathrm{http} / / /$ books.google.co.uk/books?id=sLMkCsde1u4C\&printsec=frontcover\&source=gbs_ge_s ummary_r\&cad $=0 \# \mathrm{v}=$ onepage $\& \mathrm{q} \& \mathrm{f}=$ false (Accessed: 9 th May, 2012).

[26] Hilbert, M. (2011) Towards a conceptual framework for ICT Development: lessons learned from the cube framework used in Latin America. [Online]. Available at: http://www.martinhilbert.net/HilbertCube.pdf (Accessed: 19th August, 2012).

[27] Honeyman, T., Robinson, Laura C. (2007) 'Solar Power for the Digital Fieldworker', Language Documentation \& Conservation (LD\&C), 1(1), pp. 17-27.

[28] Howell, D. (2007) Sustainable Computing. Available at: http://net.educause.edu/ir/library/pdf/NCP07077.pdf (Accessed: 26th June, 2012).

[29] IMF (2012) How does the WEO categorize advanced versus emerging and developing economies? Available at: http://www.imf.org/external/pubs/ft/weo/faq.htm\#q4b (Accessed: 13th July, 2012).

[30] International Energy Agency (2009) ENERGY BALANCES OF OECD COUNTRIES. [Online]. Available at: http://www.iadb.org/intal/intalcdi/PE/2009/04073.pdf (Accessed: 14th April, 2012).

[31] International Energy Agency. (2010) Technology Roadmap, Solar photovoltaic energy. [Online]. Available at: http://www.iea.org/papers/2010/pv_roadmap.pdf (Accessed: 11th June, 2012).

[32] Internet World Statistics.(2011) Global Internet Usage and Population Statistics. Available at: http://internetworldstats.com/ (Accessed: 10th July, 2012).

[33] IT Professional Assembly. (2011) IT Industry in Nigeria: Need for a Paradigm Shift. Available at:

http://www.cpn.gov.ng/download/2011_IT_Assembly_Papers/CPN\%20paper_IT\%20Industry \%20in\%20Nigeria_DITD.pdf (Accessed: 10 th August, 2012).

[34] Jafee, S., Siegel, P., Andrews, C. (2010) Rapid Agricultural Supply Chain Risk Assessment: A Conceptual Framework. Available at:

http://siteresources.worldbank.org/INTARD/Resources/RapApRisk_combined_web.pdf (Accessed: 12th July, 2012).

[35] Jagun, A., Somolu, O. (2010) Broadband for Nigeria: Background Document. Available at: http://bb4ng.forum.org.ng/sites/default/files/Background.pdf (Accessed: 7th March, 2012).

[36] Jaleta, M., Gardebroek, C. (2007) 'Farm-gate tomato price negotiations under asymmetric information', Journal of the International Association of Agricultural Economists., 36(2), pp. $245-251$.

[37] Kenyan Agricultural Commodity Exchange. (2010) KACE FAQs Available at: http://www.kacekenya.co.ke/faqs.asp (Accessed: 17th July, 2012). 
[38] Kirsop, B., Chan, L., Arunachalam, S. (2007) Access to Scientific Knowledge for Sustainable Development: Options for Developing Countries. Available at: http://www.ariadne.ac.uk/issue52/kirsop-et-al (Accessed: 10th May, 2012).

[39] Knowledge Sharing Toolkit.(2012) Introduction to the Toolkit. Available at: http://www.kstoolkit.org/Introduction+to+the+Toolkit (Accessed: 10th April, 2012).

[40] Low Frequency Array Project (2012) About LOFAR. Available at: www.lofar.org/ (Accessed: 10th June, 2012).

[41] Manhart, A. (2012) 'Impacts of current recycling practices and recommendations for collection and recycling', E-waste Africa Project: Pan-African Summit on E-waste. Nairobi, 14th to 16th March, 2012. Institute for Applied Ecology. Available at: http://www.oeko.de/oekodoc/1511/2012-076-en.pdf (Accessed: 17th August, 2012).

[42] Marchmont Observatory. (2005) Final Evaluation Report on the Use of ICT in Rural Industries.[Online]. Available at: www.marchmont.ac.uk/Documents/Projects/ict-in-rural.doc (Accessed: 14th June, 2012).

[43] Mittal, S., Gandi, S., and Tripathi, G (2010) 'Socio-economic Impact of Mobile Phones on Indian Agriculture'. Indian Council for Research on International Economic Relations, p. 48. Available at: http://www.icrier.org/pdf/WorkingPaper246.pdf (Accessed: 10th June, 2012).

[44] Msofe, B.H. (2008) Rural Energy Access through Off-Grid Renewables. Available at: http://siteresources.worldbank.org/EXTAFRREGTOPENERGY/Resources/717305$1264695610003 / 6743444-$ 1268073490440/4.4.REF_REA_Tanzania_offgrid_renewables.pdf1268073490440/4.4.REF_ REA_Tanzania_offgrid_renewables.pdf (Āccessed: 7th May, 2012).

[45] Mude, A., Barrett, C. B., Carter, M. R., Chantarat, S., Ikegami, M., McPeak, J. (2009) Index Based Livestock Insurance for Northern Kenya's Arid and Semi-Arid Lands: The Marsabit Pilot. [Online]. Available at: http://basis.ucdavis.edu/i4/projects/pilots/productive-safety-netkenya/files/ilbi-summary.pdf (Accessed: 11th April, 2012).

[46] Murugesan, S. (2008) Harnessing Green IT: Principles and Practices. IEEE Computer Society. Available at: http://www.cse.chalmers.se/ davidwh/eac/papers/GreenPaper.pdf (Accessed: 22nd June, 2012).

[47] Nabwowe, A. (2010) Uganda: farmers on-line. Spore. Available at: http://spore.cta.int/population/en/HS4_09report_ouganda.html (Accessed: 10th June, 2012).

[48] NASA (2012) What is GPS? Available at: http://scign.jpl.nasa.gov/learn/gps1.htm (Accessed: 15th July, 2012).

[49] Nelson, J. (2003) 'The Physics of Solar Cells', in The Physics of Solar Cells. Imperial College Press. ISBN 978-1-86094-340-9

[50] Netputting (2009) People don't know the difference between netbook and notebook. Available at: http://netputing.com/2009/06/23/people-dont-know-the-difference-betweennetbook-and-notebook/ (Accessed: 11th August, 2012).

[51] Niboh, M. (2008) 'A Bottom-up Approach to Development: The Torchbearer Foundation Model', 23rd - 25th October, 2008. Baylor University, Baylor, Texas, p. 7. Available at: http://www.baylor.edu/content/services/document.php/78925.pdf.

[52] Nordhausen, B. (2011) Solar Power for PC Deployments: Enabling ICT Beyond the Grid. Available at: http://www.intel.com/Assets/PDF/casestudies/WA-324794.pdf (Accessed: 16th May, 2012). 
[53] Nordling, L. (2010) Africa Analysis: The benefits of open source software. Available at: http://www.scidev.net/en/opinions/africa-analysis-the-benefits-of-open-source-software.html (Accessed: 5th May, 2012).

[54] OECD (2010) Greener and Smarter ICTs, the Environment and Climate Change. [Online]. Available at: http://www.oecd.org/site/stitff/45983022.pdf (Accessed: 13th June, 2012).

[55] Ogwueleka, T.C. (2009) 'Municipal Solid Waste Characteristics and Management In Nigeria', Iran Journal of Environmental Health Sci. Eng, 6(3), pp. 173-180.

[56] Pande, A. (2010) mKRISHI: Connecting India's Rural Farmers. Available at: http://www.csr360gpn.org/magazine/feature/mkrishi-connecting-indias-rural-farmers/ (Accessed: 8th June, 2012).

[57] Park, D. B., Cho, Y. B. and Lee, M. (2007) 'The Use of an e-Learning System for Agricultural Extension: A Case Study of the Rural Development Administration, Korea', The Journal of Agricultural Education and Extension, 13(4), pp. 273-285.

[58] Parliamentary Office of Science and Technology.(2008) ICT and CO2 Emissions. Available at: http://www.parliament.uk/documents/post/postpn319.pdf (Accessed: 20th July, 2012).

[59] PC Magazine. (2012) Radio. Available at: http://www.pcmag.com/encyclopedia_term/0,1237,t=radio\&i $=50130,00$.asp

[60] Pearsall, N. (2012) SPG8017: Introduction to Bioenergy and Photovoltaics. Lecture Notes. University of Newcastle. 25pp.

[61] Royal Academy of Engineering. (RAE, 2012) The future of computing: indispensable or unsustainable?[Online]. Available at: www.raeng.org.uk/futurecomputing (Accessed: 18th May, 2012).

[62] Ruth, S. 2012 (2011) 'Reducing ICT-related Carbon Emissions: An Exemplar for Global Energy Policy?'.pp. 207-211 28. Available at: http://tr.ietejournals.org/text.asp?2011/28/3/207/81229 (Accessed: 19th June, 2012).

[63] Serrano, D. (2003) 'Solar powered module for portable computers', Journal of Solar Energy Engineering, 125(2), pp. 207-211.

[64] Serrano, D. (2003) 'Solar Powered Module for Portable Computers', Journal of Solar Energy Engineering 125(2, 207), p. 5.

[65] Sorrel, S., Speirs, J., Bentley, R., Brandt, A., Miller, R. (2009) Global Oil Depletion: An assessment of the evidence for a near-term peak in global oil production (ISBN Number: 1903144-0-35). Australian Institute of Energy: CENTRE, U.E.R. [Online]. Available at: http://aie.org.au/Content/NavigationMenu/OilGasSIG/InterestingUsefulArticles/Global_Oil_ Depletion_UKERC.pdf.

[66] Timilsina, G.R., Kurdgelashvili, L., Narbel, P. (2011) A Review of Solar Energy Markets, Economics and Policies.[Online]. Available at: http://wwwwds.worldbank.org/servlet/WDSContentServer/WDSP/IB/2011/10/17/000158349_20111017 113749/Rendered/PDF/WPS5845.pdf (Accessed: 18th July, 2012).

[67] UN (2011) Composition of macro geographical (continental) regions, geographical subregions, and selected economic and other groupings Available at: http://unstats.un.org/unsd/methods/m49/m49regin.htm\#ftnc

[68] USAID (2011) Selecting Mobile ICT Devices for Agriculture Services and Applications in sub-Saharan Africa. [Online]. Available at: https://communities.usaidallnet.gov/ictforag/node/197 (Accessed: 17th July, 2012). 
[69] Webopedia (2012) Mobile Phone. Available at:

http://www.webopedia.com/TERM/M/mobile_phone.html (Accessed: 18th April, 2012).

[70] Webopedia (2012) What is a Computer? Available at:

http://www.webopedia.com/TERM/C/computer.html (Accessed: 13th July, 2012).

[71] Wingfield, B. (2011) GE Sees Solar Cheaper Than Fossil Power in Five Years. Available at: http://www.bloomberg.com/news/2011-05-26/solar-may-be-cheaper-than-fossil-power-infive-years-ge-says.html (Accessed: 10th July, 2012).

[72] World Bank. (2012) ICT in Agriculture Sourcebook: Connecting Smallholders to Knowledge, Networks, and Institutions (64605). [Online]. Available at:

http://www.ictinagriculture.org/ictinag/node/105 (Accessed: 30th January, 2012).

[73] World Bank. (ND) How we Classify Countries Available at:

http://data.worldbank.org/about/country-classifications (Accessed: 12th March, 2012).

[74] World Summit on Information Society. (2005) What's the State of ICTs around the World? Available at: http://www.itu.int/wsis/tunis/newsroom/stats/index.html

[75] Zhang, J.-C., Pu, R.-l., Wang, J.-h., Huang, W.-J., Yuan, L. and Luo, J.-h. (2012) 'Detecting powdery mildew of winter wheat using leaf level hyperspectral measurements', Computers and Electronics in Agriculture, 85(0), pp. 13-23. 